\title{
Correlation and heritability estimates of seedling traits under salt stress conditions of bread wheat genotypes
}

\author{
Naila Gandahi ${ }^{*}$, Abdul Wahid Baloch ${ }^{1}$, Muhammad Jurial Baloch ${ }^{1}$ and \\ Muhammad Ubaidullah Shirazi ${ }^{2}$ \\ 1. Department of Plant Breeding and Genetics, SAU, Tandojam-Pakistan \\ 2. Nuclear Institute of Agriculture, Tandojam-Pakistan \\ *Corresponding author's email: gandahinaila@gmail.com \\ Citation \\ Naila Gandahi, Abdul Wahid Baloch, Muhammad Jurial Baloch and Muhammad Ubaidullah Shirazi. Correlation \\ and heritability estimates of seedling traits under salt stress conditions of bread wheat genotypes. Pure and Applied \\ Biology. Vol. 8, Issue 1, pp127-132. http://dx.doi.org/10.19045/bspab.2018.700170
}

\begin{tabular}{llll}
\hline \hline Received: 30/07/2018 & Revised: 24/09/2018 & Accepted: 12/10/2018 & Online First: 15/10/2018 \\
\hline
\end{tabular}

\section{Abstract}

The current study was aimed to estimate correlation and heritability of different seedling and physiological attributes of Triticum aestivum L. genotypes under normal and salinity stress conditions. In this context, a set of 22 bread wheat genotypes were grown in CRD with three replications having two treatments (control and $12 \mathrm{dSm}^{-1}$ ). Mean squares from analysis of variance demonstrated significant $(\mathrm{P} \leq 0.01)$ with respect to treatment effect, genotype differences and treatment $\mathrm{x}$ genotype interaction on all studied parameters, revealing that evaluated bread wheat genotypes possessed valuable genetic resources, which may further be exploited in future breeding programs. With regard to correlation results obtained from normal and salinity stress conditions, the traits root length and shoot length associated positively and significantly with other seedling and physiological traits, suggesting that rise in any seedling/physiological trait congruently improve the other traits. Considering the heritability estimates, all traits showed high heritability under normal and stress conditions. The occurrence of high broad sense heritability in the present investigation demonstrated the suitability of genotypes for breeding programs for stress environments.

Keywords: Bread wheat; Correlation; Heritability; Salinity; Seedling traits

\section{Introduction}

To obtain superior yield with potential resistance against biotic and abiotic stresses in Pakistani bread wheat cultivars, many breeding efforts had been done in the recent past; consequently, due to its bidirectional breeding approaches a number of promising cultivars with better adaptability have also been released. Wheat has a unique position among cereal crops, mostly attributable to the reason that grains retain protein with exceptionally good chemical and physical properties [1]. Correlation is a statistical technique that can show whether and how strongly pairs of variables are related. Among useful breeding characteristics, genotypic and phenotypic correlations are applied to determine extent of correlation of certain yield contributing traits with yield [2]. The correlation coefficients commonly are the 
associations among different independent variables and the extent of linear relations. These variables could not describe association adequately in case apparent cause-result relationship is found among variables [3]. Heritability tends to have a great role in breeding, communicating the consistency of phenotype value as a guide to its breeding value. It is assumed that breeding value can only be derived from appropriate analyses when there is phenotypic value are being measured, while breeding value can suggests that what extent of phenotype would be conceded to the coming generation [4]. Not a huge achievement has been obtained in plant breeding with respect to improve the adaptation of crops against salinity. The limited genetic resources with regard to salinity stress in elite bread wheat genotypes advocate that selection due to domestication has turned against the ability for salt tolerance. The presence of negative associations between genetic recombination of high yielding and salt tolerance may be a key cause towards the reduction of desirable genes for salinity stress [5]. The breeding programs with successful results depend on a collection of various genetic resources [6]. After evaluation, genetic materials indicate the estimation of progeny performance on the basis of heritable and non-heritable variation, and therefore satisfactory selections can be made on the basis of heritability [7]. The study was designed to estimate correlation and heritability for various seedling and physiological traits of bread wheat genotypes under normal and salt stress conditions.

\section{Materials and methods}

This study was aimed to estimate correlation and heritability under control and salinity stress conditions. In this regard, twenty two wheat genotypes of diverse origin were used such as NIA-Sundar, NIA-Sarang, NIA-AS14, NIA-AS-9, NIA-AS-10, NIA-2B, Hamal, NIA-5B, Salt-6, SRN-87, SRN-11, CT-49, NRC-1236, Bathoor-08, Tatara, TJ-83, TD-1,
Benazir, AS-2002, Sehar-2006, Kiran-95 and LU-26s for seedling and physiological traits under salinity stress conditions. The experiment was laid out in complete randomized design with three replications having two treatments (control and $12 \mathrm{dSm}^{-1}$ ). The experiment was conducted in water culture using $1 / 4^{\text {th }}$ strength of Hoagland nutrient solution as growing media in plastic bowls (Size: $8.4 \times 4.5 \mathrm{~cm}$ ). Seeds were planted on molded plastic sieves placed in plastic bowls, containing sufficient nutrient solution. The bowls were placed in programmed controlled growth cabinets maintain at $25 / 20^{\circ} \mathrm{C}$ day/night temperatures and 12 hours photoperiod. The experiment was terminated after 10 days (240 hours). The analysis of variances and correlation of coefficient was calculated with the help of computer package (Statistix Ver. 8.1), while heritability in broad sense was estimated as suggested by Allard [8].

\section{Results and discussion}

Mean squares from analysis of variance displayed significant treatment effect $(\mathrm{P} \leq$ 0.01 ) on all studied parameters (Table 1). Mean squares from analysis of variance demonstrated significant $(\mathrm{P} \leq 0.01)$ with respect to treatment effect, genotype differences and treatment $\mathrm{x}$ genotype interaction on all studied parameters, revealing that evaluated bread wheat genotypes possessed valuable genetic resources, exhibiting that used 22 bread wheat genotypes tend to possess valuable genetic resources, which may further be utilized in breeding programs. Similar to these results, Naggar et al. [9] reported that genotypes, treatments and their interaction were significant for all evaluated parameters. Akbarpour et al. [7] also evaluated a set of different wheat landraces in both conditions (normal and salt stress) and observed that mean squares of all traits indicated significant differences among used genotypes. 
Correlations are very important in crop sciences because of its useful in disclosing the magnitude and direction of the relationship between various yield contributing traits and yield. Correlation studies give a clear picture of characters association which is generally due to linkage, pleiotrophy, physiological association in developmental and biochemical pathway. The characters which are correlated are of much interest since change in one character influenced the other one [10]. In the present study, the obtained correlations results under normal conditions (Table 2) showed that root length made positive and significant associations with root fresh weight $(\mathrm{r}=$ $\left.0.39^{* *}\right)$ and shoot fresh weight $\left(\mathrm{r}=0.28^{*}\right)$; shoot length correlated significantly and positively with $\mathrm{Na}^{+} / \mathrm{K}^{+}$ratio $\left(\mathrm{r}=0.55^{* *}\right)$, while also showed significant and negative correlations with root fresh weight $(\mathrm{r}=$ $\left.0.39^{* *}\right)$ and $\mathrm{Na}^{+}\left(\mathrm{r}=-0.37^{* * *}\right)$; root fresh weight depicted positive and significant correlation with shoot fresh weight $\left(r=0.28^{*}\right)$ but negatively and significantly associated with $\mathrm{Na}^{+} / \mathrm{K}^{+}$ratio $\left(\mathrm{r}=-0.24^{*}\right)$; whereas $\mathrm{Na}^{+}$ showed negative and significant associated $(\mathrm{r}$ $=-0.34^{* *}$ ) and $\mathrm{K}^{+}$associated positively and significant with $\mathrm{Na}^{+} / \mathrm{K}^{+}$ratio $\left(\mathrm{r}=0.60^{* *}\right)$. Regarding the correlations under salt stress conditions (Table 3), root length made positive and significant associations with shoot length $\left(\mathrm{r}=0.43^{* *}\right)$, root fresh weight $(\mathrm{r}$ $\left.=0.37^{* *}\right)$, shoot fresh weight $\left(\mathrm{r}=0.49^{* *}\right), \mathrm{K}^{+}$ $\left(\mathrm{r}=0.53^{* *}\right)$ and $\mathrm{Na}^{+} / \mathrm{K}^{+}$ratio $\left(\mathrm{r}=0.62^{* *}\right)$, while also showed significant but negative correlation with $\mathrm{Na}^{+}\left(\mathrm{r}=-0.55^{* *}\right)$. Shoot length associated positively and significantly with shoot fresh weight $\left(\mathrm{r}=0.35^{* *}\right), \mathrm{K}^{+}(\mathrm{r}=$ $\left.0.52^{* *}\right)$ and $\mathrm{Na}^{+} / \mathrm{K}^{+}$ratio $\left(\mathrm{r}=0.69^{* * *}\right)$, while also demonstrated significant but negative association with $\mathrm{Na}^{+}\left(\mathrm{r}=-0.67^{* *}\right)$. Root fresh weight exhibited positive and significant associations with shoot fresh weight $(\mathrm{r}=$ $\left.0.58^{* *}\right)$ and $\mathrm{Na}^{+} / \mathrm{K}^{+}$ratio $\left(\mathrm{r}=0.25^{*}\right)$, however, also showed significant but negative association with $\mathrm{Na}^{+}\left(\mathrm{r}=-0.38^{* *}\right)$. Furthermore, the $\mathrm{Na}^{+}$showed negative and significant correlations with shoot fresh weight $\left(\mathrm{r}=-0.51^{* *}\right), \mathrm{K}^{+}\left(\mathrm{r}=-0.35^{* *}\right)$ and $\mathrm{Na}^{+} / \mathrm{K}^{+}$ratio $\left(\mathrm{r}=-0.77^{* * *}\right)$. While shoot fresh weight $\left(\mathrm{r}=0.48^{* *}\right)$ and $\mathrm{K}^{+}\left(\mathrm{r}=0.82^{* *}\right)$ developed positive and significant correlations with $\mathrm{Na}^{+} / \mathrm{K}^{+}$ratio. The results obtained from normal and salinity stress conditions, the traits root length and shoot length associated positively and significantly with other seedling and physiological traits, signifying that rise in any seedling/physiological trait congruently improve the other traits. This unveils that if single trustworthy trait is picked in salinity stress and that may be used as a selection criterion that will certainly lead to improve other seedling traits for salt stress conditions and improved genotypes could be selected to get along with stress environments. Dashti et al. [11] observed a significantly negative associations between $\mathrm{K}^{+} / \mathrm{Na}^{+}$and $\mathrm{Na}^{+}$ concentration, while $\mathrm{K}^{+} / \mathrm{Na}^{+}$was significantly and positively interrelated with $\mathrm{K}^{+}$. Moreover, these results are also in agreement with those of Dehdari et al. [12] and Dashti et al. [13].

Information on heritability is necessary for plant breeders. It has been predicted that increase of stress levels cause changes in heritability [14]; and such variations in heritability were also observed by Hoffmann and Parsons [15]. The decrease or increase in genetic variation would appear possibly due to increased stress, since diverse genes may contribute to similar character under varied environments [16]. With respect to heritability results (Table 4), high heritability were estimated for majority of characters under stress environments, such as root length $\left(\mathrm{h}^{2}=99.02 \%\right)$, shoot length $\left(\mathrm{h}^{2}\right.$ $=81.28 \%)$, root fresh weight $\left(\mathrm{h}^{2}=98.33 \%\right)$, shoot fresh weight $\left(\mathrm{h}^{2}=99.52 \%\right), \mathrm{K}^{+}\left(\mathrm{h}^{2}\right.$ $=93.27 \%)$ and $\mathrm{Na}^{+} / \mathrm{K}^{+}$ratio $\left(\mathrm{h}^{2}=99.37 \%\right)$; however, low but desirable heritability 
estimated for $\mathrm{Na}^{+}\left(\mathrm{h}^{2}=2.20 \%\right)$. Similarly, high heritability was also estimated for all the studied traits under salt stress conditions, such as root length $\left(\mathrm{h}^{2}=84.17 \%\right)$, shoot length $\left(\mathrm{h}^{2}=84.05 \%\right)$, root fresh weight $\left(\mathrm{h}^{2}\right.$ $=93.96 \%)$, shoot fresh weight $\left(\mathrm{h}^{2}=94.83 \%\right)$, $\mathrm{Na}^{+}\left(\mathrm{h}^{2}=96.74 \%\right), \mathrm{K}^{+}\left(\mathrm{h}^{2}=92.60 \%\right)$ and $\mathrm{Na}^{+} / \mathrm{K}^{+}$ratio $\left(\mathrm{h}^{2}=99.55 \%\right)$. The presence of high heritabilities in the current research exhibited that genotypes were suitable for breeding programs while considering stress environments. Most of the research studies suggest that improvement in crop salt tolerance is not at rapid pace since a limited knowledge is existed for numerous complex tolerance mechanisms and absence of variation for salt affected traits [5].

Table 1. Mean squares of different seedling traits of bread wheat genotypes

\begin{tabular}{|c|c|c|c|c|c|c|c|c|}
\hline $\begin{array}{c}\text { Sources of } \\
\text { variances }\end{array}$ & $\begin{array}{c}\text { Degree of } \\
\text { freedom }\end{array}$ & $\begin{array}{c}\text { Root } \\
\text { length }\end{array}$ & $\begin{array}{c}\text { Shoot } \\
\text { length }\end{array}$ & $\begin{array}{c}\text { Root } \\
\text { fresh } \\
\text { weight }\end{array}$ & $\begin{array}{c}\text { Shoot } \\
\text { fresh } \\
\text { weight }\end{array}$ & $\mathbf{N a}^{+}$ & $\mathbf{K}^{+}$ & $\begin{array}{c}\mathbf{N a}^{+} / \mathbf{K}^{+} \\
\text {ratio }\end{array}$ \\
\hline Replication & 2 & 1.51 & 5.17 & 0.01 & 0.02 & 357.90 & 15.56 & 0.01 \\
\hline Genotypes (G) & 21 & $7.90^{* *}$ & $75.09^{* *}$ & $0.23^{* *}$ & $0.93^{* *}$ & $233.90^{* *}$ & $192.09^{* *}$ & $0.25^{* *}$ \\
\hline Treatments (T) & 1 & $175.76^{* *}$ & $545.38^{* *}$ & $1.96^{* *}$ & $22.72^{* *}$ & $11232.50^{* *}$ & $3186.00^{* *}$ & $8.28^{* *}$ \\
\hline G x T & 21 & $2.57^{* *}$ & $5.95^{* *}$ & $0.07^{* *}$ & $0.05^{* *}$ & $45.30^{* *}$ & $51.68^{* *}$ & $0.01^{* *}$ \\
\hline Error & 86 & 0.70 & 1.85 & 0.01 & 0.01 & 13.40 & 13.46 & 0.001 \\
\hline
\end{tabular}

** shows significant differences at $1 \%$ of probability level

Table 2. Correlations of coefficient between different seedling traits of bread wheat genotypes under normal conditions

\begin{tabular}{|c|c|c|c|c|c|c|}
\hline Traits & $\begin{array}{c}\text { Root } \\
\text { length }\end{array}$ & $\begin{array}{c}\text { Shoot } \\
\text { length }\end{array}$ & $\begin{array}{c}\text { Root fresh } \\
\text { weight }\end{array}$ & $\begin{array}{c}\text { Shoot fresh } \\
\text { weight }\end{array}$ & $\mathbf{N a}^{+}$ & $\mathbf{K}+$ \\
\hline Shoot length & 0.11 & & & & & \\
\hline Root fresh weight & $0.39^{* *}$ & $-0.39^{* *}$ & & & & \\
\hline Shoot fresh weight & $0.28^{*}$ & 0.09 & $0.28^{*}$ & & & \\
\hline $\mathrm{Na}^{+}$ & -0.09 & $-0.37^{* *}$ & 0.18 & -0.13 & & \\
\hline $\mathrm{K}^{+}$ & 0.06 & 0.12 & 0.02 & 0.08 & 0.10 & \\
\hline $\mathrm{K}^{+} / \mathrm{Na}^{+}$ratio & 0.20 & $0.55^{* *}$ & $-0.24^{*}$ & 0.21 & $-0.34^{* *}$ & $0.60^{* *}$ \\
\hline
\end{tabular}

$* *, *$ show significant differences at 1 and $5 \%$ of probability level

Table 3. Correlations of coefficient between different seedling traits of bread wheat genotypes under salt stress conditions

\begin{tabular}{|c|c|c|c|c|c|c|}
\hline Traits & $\begin{array}{c}\text { Root } \\
\text { length }\end{array}$ & $\begin{array}{c}\text { Shoot } \\
\text { length }\end{array}$ & $\begin{array}{c}\text { Root fresh } \\
\text { weight }\end{array}$ & $\begin{array}{c}\text { Shoot fresh } \\
\text { weight }\end{array}$ & $\mathbf{N a}^{+}$ & $\mathbf{K}^{+}$ \\
\hline Shoot length & $0.43^{* *}$ & & & & & \\
\hline Root fresh weight & $0.37^{* *}$ & 0.10 & & & & \\
\hline Shoot fresh weight & $0.49^{* *}$ & $0.35^{* *}$ & $0.58^{* *}$ & & & \\
\hline $\mathrm{Na}^{+}$ & $-0.55^{* *}$ & $-0.67^{* *}$ & $-0.38^{* *}$ & $-0.51^{* *}$ & & \\
\hline $\mathrm{K}^{+}$ & $0.53^{* *}$ & $0.52^{* *}$ & 0.13 & 0.23 & $-0.35^{* *}$ & \\
\hline $\mathrm{K}^{+} / \mathrm{Na}^{+}$ratio & $0.62^{* *}$ & $0.69^{* *}$ & $0.25^{*}$ & $0.48^{* *}$ & $-0.77^{* *}$ & $0.82^{* *}$ \\
\hline
\end{tabular}

$* *, *$ show significant differences at 1 and $5 \%$ of probability level 
Table 4. Heritability estimates (broad sense) of different seedling traits of bread wheat genotypes under salt stress conditions

\begin{tabular}{|c|c|c|c|c|c|c|}
\hline \multirow{2}{*}{ Traits } & \multicolumn{3}{|c|}{ Normal conditions } & \multicolumn{3}{c|}{ Salinity stress conditions } \\
\cline { 2 - 7 } & $\begin{array}{c}\text { Genotypic } \\
\text { variance } \\
\left(\boldsymbol{\delta}^{\mathbf{2}} \mathbf{g}\right)\end{array}$ & $\begin{array}{c}\text { Phenotypic } \\
\text { variance } \\
\left(\boldsymbol{\delta}^{\mathbf{2}} \mathbf{p}\right)\end{array}$ & $\begin{array}{c}\text { Heritability } \\
\boldsymbol{\%}(\mathbf{B r o a d} \\
\text { sense) }\end{array}$ & $\begin{array}{c}\text { Genotypic } \\
\text { variance } \\
\left(\boldsymbol{\delta}^{2} \mathbf{g}\right)\end{array}$ & $\begin{array}{c}\text { Phenotypic } \\
\text { variance } \\
\left(\boldsymbol{\delta}^{\mathbf{2}} \mathbf{p}\right)\end{array}$ & $\begin{array}{c}\text { Heritability } \\
\boldsymbol{\%} \\
(\text { Broad } \\
\text { sense) }\end{array}$ \\
\hline Root length & 22.64 & 22.86 & 99.02 & 9.10 & 10.81 & 84.17 \\
\hline Shoot length & 4.70 & 5.78 & 81.28 & 18.42 & 21.92 & 84.05 \\
\hline Root fresh weight & 59.00 & 60.00 & 98.33 & 23.34 & 24.84 & 93.96 \\
\hline Shoot fresh weight & 209.00 & 210.00 & 99.52 & 36.71 & 38.71 & 94.83 \\
\hline $\mathrm{Na}^{+}$ & 0.18 & 8.16 & 2.20 & 31.39 & 32.45 & 96.74 \\
\hline $\mathrm{K}^{+}$ & 6.02 & 6.45 & 93.27 & 11.43 & 12.35 & 92.60 \\
\hline $\mathrm{K}^{+} / \mathrm{Na}^{+}$ratio & 15.84 & 15.94 & 99.37 & 55.62 & 55.87 & 99.55 \\
\hline
\end{tabular}

\section{Conclusion}

It was concluded from results that root length and shoot length correlated positively and significantly with other seedling and physiological traits, signifying that increase in any seedling/physiological trait correspondingly improve the other traits. Moreover, all traits showed high heritability under normal and stress conditions. The occurrence of high broad sense heritability in the present study established the suitability of genotypes for breeding programs for stress environments.

\section{Authors' contributions}

Conceived and designed the experiments: MU Shirazi \& N Gandahi. Performed the experiments: N Gandahi, Analyzed the data: N Gandahi \& MJ Baloch, Contributed reagents/ materials/ analysis tools: MU Shirazi, Wrote the paper: AW Baloch \& N Gandahi.

\section{References}

1. Ali MA, Nawab NN, Rasool G \& Saleem M (2013). Estimates of variability and correlations for quantitative traits in Cicer arietinum L. J Agri Social Sci 4(4): 177-179.

2. Ali Y, Atta BM, Akhter J, Monneveux P \& Lateef Z (2008). Genetic variability, association and diversity studies in wheat germplasm (Triticum aestivum L.). Pak J Bot 40(5): 2087-2097.

3. Dokuyucu T, Akkaya A \& Akcura M
(2002). Path analysis of yield and some yield related traits of Durum wheat genotypes grown in rain-fed conditions of Mediterranean Region. Turk J Field Crops 7(1): 31-39.

4. Larik AS, Malik SI, Kakar AA \& Naz MA (2000). Assessment of heritability and genetic advance for yield and yield components in Gossypium hirsutum L. Sci Khyber 13: 39-44.

5. Botella MA, Rosado A, Bressan RA \& Hasegawa PM (2005) Plant adaptive responses to salinity stress. In 'Plant abiotic stress'. (Eds MA Jenks, PM Hasegawa) Blackwell Publishing: Oxford, UK pp 38-62.

6. Flowers TJ (2004). Improving crop salt tolerance. J Exp Bot 55: 307-319.

7. Akbarpour OA, Dehghani H \& Rousta MJ (2015). Evaluation of salt stress of Iranian wheat germplasm under field conditions. Crop Past Sci 66: 770-781.

8. Allard RW (1960 Principles of Plant Breeding. John Wiley and Sons, Inc. New York USA.

9. Naggar AMM, Sabry SRS, Atta MMM \& Abd El Aleem OM (2015). Effects of salinity on performance, heritability, selection gain and correlations in wheat (Triticum aestivum L.) doubled haploids. Sci Agri 10(2): 70-83.

10. Chitralekha PK, Chandrakar NK, Banjare U \& Densena M (2018). 
Estimation of correlation coefficient study of some quantitative traits in wheat. Ann Plant Sci 7(2): 2078-2081.

11. Dashti H, Bihamta MR, Shirani H \& Majidi MM (2012). Genetic analysis of salt tolerance in vegetative stage in wheat (Triticum aestivum). Plant Omics J 5(1): 19-23.

12. Dehdari A, Rezai A \& Mirmohammadi SA (2005). Salt tolerance of seedling and adult bread wheat plants based on ion contents and agronomic traits. Comm Soil Sci Plant 36: 2239-2253.

13. Dashti H, Naghavi MR \& Tajabadipour
A (2010). Genetic analysis of salinity tolerance in a bread wheat cross. J Agri Sci Tech 12: 347-356.

14. Blum A. (1988) Plant Breeding for Stress Environment. CRC Pres Inc Boca Raton, Florida.

15. Hoffman AA \& Parsons PA (1991). Evolutionary Genetics and Environmental Stress. Oxford University Press. Paper 284.

16. Rumbaugh MD, Asay KH \& Johnson DA (1984). Influence of drought stress on genetic variance of alfalfa and wheat grass seedling. Crop Sci 24: 297-303. 